Anales

Médicos

dx.doi.org/10.35366/BC194A

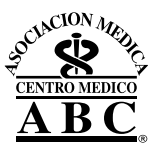

Vol. 64, Núm. 4

Oct. - Dic. 2019

p. 240

\title{
La otorrinolaringología; mucho más que sólo oído, nariz y garganta
}

\author{
Otolaryngology; much more than just ear, nose and throat
}

\section{Daniel Bross Soriano*}

La otorrinolaringología es una especialidad multifacética, cuando empezó era oídos, ojos, nariz y garganta. A principios del siglo XX, la oftalmología se separó de nuestra especialidad, y en ese momento hubiera parecido que nuestro campo de trabajo se estrechaba cada vez más: nada más alejado de la realidad.

En este número de la revista —que la práctica médica grupal de otorrinolaringología dedica a nuestra especialidad - vemos cómo cada día se expande a las regiones aledañas y tenemos escritos que van desde la detección temprana de las alteraciones de los sentidos, como la audición y el habla, hasta el tratamiento de enfermedades tumorales y/o degenerativos del adulto mayor, pasando por el trauma a la zona, lesiones por arma de fuego, etcétera.

Es un verdadero placer mostrar cómo nuestra especialidad es cada vez más amplia e incluye diferentes subespecialidades, así como el trabajo en equipo con otras especialidades afines.

Como práctica médica grupal, éste es el segundo número que logramos completar de nuestra especialidad. Esperemos que esto se vuelva una costumbre recurrente dentro de nuestra revista.

\footnotetext{
* Otorrinolaringología y cirugía endoscópica de nariz y senos paranasales.
} 